\title{
52. LIPID GEOCHEMISTRY OF CRETACEOUS/TERTIARY BOUNDARY SEDIMENTS, HOLE 605, DEEP SEA DRILLING PROJECT LEG 93, AND STEVNS KLINT, DENMARK ${ }^{1}$
}

\author{
Bernd R. T. Simoneit and Harry R. Beller, Oregon State University ${ }^{2}$
}

\begin{abstract}
This reconnaissance study was undertaken to determine whether the mass extinctions and faunal successions that mark the Cretaceous/Tertiary $(\mathrm{K} / \mathrm{T})$ boundary left a discernible molecular fossil record in the sediments of this period. Lipid signatures of sediments taken from above and below the $\mathrm{K} / \mathrm{T}$ boundary were compared in core and outcrop samples taken from two locations: the U.S. east coast continental margin (western Atlantic Ocean, DSDP Site 605) and Stevns Klint, Denmark. Four calcareous sediments taken from above and below the K/T boundary in DSDP Hole 605, Section 605-66-1, revealed changing lipid signatures between above and below that are characterized by a large component of unresolved naphthenic hydrocarbons and a homologous series of $n$-alkanes ranging from $C_{16}$ to $C_{33}$. These lipid signatures are attributed to an influx of a terrestrial higher plant component and to bacterial reworking of the sediments under partially anoxic depositional and/or diagenetic conditions. The outcrop samples from Stevns Klint had extremely low concentrations of indigenous lipids. The fish clay at the $\mathrm{K} / \mathrm{T}$ boundary contained traces of microbial hydrocarbons and fatty acids, whereas the carbonates above and below had only microbial fatty acids and additional terrestrial resin acids. The data from both sites indicate a perturbation in the deposition of lipid compound classes across the $\mathrm{K} / \mathrm{T}$ boundary.
\end{abstract}

\section{INTRODUCTION}

The Cretaceous/Tertiary $(\mathrm{K} / \mathrm{T})$ boundary is marked by major extinctions of both marine and terrestrial species. These extinctions may have been caused by extensive volcanic activity or by the impact of a massive extraterrestrial body (Alvarez et al., 1980, 1984), possibly of meteoritic origin according to current data on Ir and Os anomalies (Alvarez et al., 1982, 1984; Luck and Turekian, 1983). A major meteoritic impact could have had extensive biogeochemical consequences, such as the cessation or dramatic reduction of photosynthetic biomass production on a regional to global scale, possibly caused by wildfires and/or the scouring of continents by tidal waves (e. g., Wolbach et al., 1985). Presumably, a reduction of biogenesis, a possible hiatus or facies change at the $\mathrm{K} / \mathrm{T}$ boundary, and a subsequent, gradual buildup of extant and new species should have left a molecular fossil record in the sediments. The purpose of this preliminary analysis is to evaluate such a possibility.

The samples for this study are from Hole 605, Core 66 , located on the U.S. east coast continental rise $\left(38^{\circ}\right.$ $43.08^{\prime} \mathrm{N}, 72^{\circ} 33.64^{\prime} \mathrm{W}, 2338 \mathrm{~m}$ water depth) (van Hinte, Wise, et al., 1984, 1985) and from the Stevns Klint section exposed in an outcrop at Højerup, Denmark (Christensen et al., 1973). The sediment of Core 66, Section 1, consists of silt and foraminifer-rich clayey nannofossil limestone (greenish gray, 5G 5/1) above the K/T boundary and clay-rich nannofossil limestone with some quartz and foraminifers (gray, 5Y 5.5/1) below (Site 604/605 chapter, this volume). The $\mathrm{K} / \mathrm{T}$ boundary was assigned

\footnotetext{
${ }^{1}$ van Hinte, J. E., Wise, S. W., Jr., et al., Init. Repts. DSDP, 93: Washington (U.S. Govt, Printing Office).

2 Address: Biogeochemistry and Chemical Evolution Group, College of Oceanography, Oregon State University, Corvallis, OR 97331.
}

within an erosional feature at about $72 \mathrm{~cm}$ in Core 66 , Section $1(43-75 \mathrm{~cm})$, although Habib and Drugg (this volume) identify the K/T boundary between 64 and 78 $\mathrm{cm}$ in Section 605-66-1 based on dinoflagellate microfossils. They find good agreement with the Stevns Klint record.

The Stevns Klint section is the type locality of the Danian (Christensen et al., 1973) and was sampled 15 $\mathrm{cm}$ above and below and in the fish clay at the $\mathrm{K} / \mathrm{T}$ boundary. The upper Maestrichtian sample (2-10) is a gray Bryozoan chalk and the basal Danian sample (2-12) is a limestone with Thalassinoides and hardground facies (S. Gartner, private communication). The sample of fish clay (2-11) is a laminated marl, and the clay fraction has been found to consist of pure smectite with $>95 \%$ expandable layers (Kastner et al., 1984). This was interpreted as in situ clay formation by alteration of impact glass, which was further supported by the high content of Ir and major element chemistry.

\section{EXPERIMENTAL}

The DSDP Hole 605 samples were freeze-dried and exhaustively extracted with azeotropic toluene:methanol in a Soxhlet apparatus; each extract was concentrated by rotary evaporation and was subjected to thin-layer chromatography (6.5\% ethyl ether:hexane). The elution region corresponding to hydrocarbons was analyzed by gas chromatography (GC) and gas chromatography-mass spectrometry (GC-MS).

The Stevns Klint samples were dissolved in $1 \mathrm{~N} \mathrm{HCl}$, and the aqueous, acidic solutions were exhaustively extracted with hexane in a separatory funnel. Undissolved sediment residues were extracted by ultrasonic agitation; both organic extracts for each sample were combined and concentrated on a rotary evaporator. The concentrated extracts were treated with diazomethane in diethyl ether to derivatize free fatty acids. These total extracts were then subjected directly to GC and GCMS.

Given the expected low concentrations of lipids to be measured, the following normal precautions of good laboratory practice were carried out to reduce potential contamination. All solvents were of distilled-in-glass (nanno grade) quality, glassware was acid-cleaned prior to use, and procedural blanks were monitored to preclude problems. 
The GC analyses were carried out on a Varian Vista 44 gas chromatography system using a $30 \mathrm{~m} \times 0.25 \mathrm{~mm}$ fused silica capillary column coated with DB-5 ( $\mathrm{J}$ and W Scientific, Inc.) and programmed from 65 to $130^{\circ} \mathrm{C}$ at $10^{\circ} \mathrm{C} / \mathrm{min}$. and then from 130 to $275^{\circ} \mathrm{C}$ at $5^{\circ} \mathrm{C}$ / min.; helium was the carrier gas.

The GC-MS analyses were performed on a Finnigan 4021 quadrupole mass spectrometer interfaced directly to a Finnigan 9610 gas chromatograph, equipped with a $30 \mathrm{~m} \times 0.25 \mathrm{~mm}$ fused silica capillary column coated with DB-5. The GC for the GC-MS analyses was programmed from 60 to $310^{\circ} \mathrm{C}$ at $4^{\circ} \mathrm{C} / \mathrm{min}$. The mass spectrometric data were acquired and processed with a Finnigan-Incos 2300 data system.

Total organic carbon values were determined for samples above and below the K/T boundary by the phosphoric acid/dichromate oxidation technique (described in Weliky et al., 1983).

\section{RESULTS AND DISCUSSION}

\section{Hole 605}

The sample descriptions and analytical data are summarized in Table 1. The organic carbon contents for the samples from Hole 605 are low $(\sim 0.2 \%)$ and they have a moderate carbonate content. The hydrocarbon yields are also low, but definitely above background (0.3-1.2 $\mu \mathrm{g} / \mathrm{g})$.

Hydrocarbon distributions are shown in Figure 1, and the dominant homologs are $n$-alkanes ranging from $\mathrm{C}_{13}$ to $\mathrm{C}_{33}$. All samples exhibit an $n$-alkane maximum at $\mathrm{C}_{17}$ or $\mathrm{C}_{18}$ and a carbon preference index (CPI, cf. Table 1) of approximately one from $C_{13}$ to $C_{22}$. This is indicative of a degraded lipid residue from microbiota, especially bacteria (Simoneit, 1981, 1982). In the GC data of all samples there is a major component of unresolved branched and cyclic hydrocarbons (hump) ranging from $\mathrm{C}_{16}$ to $\mathrm{C}_{24}$ retention time with a maximum at $\mathrm{C}_{20}$ to $\mathrm{C}_{21}$. This hump is interpreted to represent a degraded residue of algal lipids (Simoneit, 1981, 1982). It could also represent a small contribution of recycled sediment containing more mature bitumen with a "petroleum-type" signature. The $n$-alkanes $>C_{23}$ exhibit different distri- butions for samples above versus below the $\mathrm{K} / \mathrm{T}$ boundary. There is a major terrestrial vascular plant-wax component in the samples below the $\mathrm{K} / \mathrm{T}$ boundary (dominant odd-carbon-chain homologs maximizing at $n-\mathrm{C}_{29}$, Fig. 1C, D; Simoneit, 1978, 1982), whereas above the $\mathrm{K} / \mathrm{T}$ boundary, this signal is greatly reduced (Fig. 1B) and microbially altered (Fig. 1A). The pristane-to-phytane ratio $(\mathrm{Pr} / \mathrm{Ph})$ is $>1$ below the $\mathrm{K} / \mathrm{T}$ boundary and $<1$ above. Although elemental sulfur is not present in these samples, the $\mathrm{Pr} / \mathrm{Ph}$ can be interpreted to indicate relatively oxygen-depleted (euxinic) environmental conditions above the $\mathrm{K} / \mathrm{T}$ boundary, with normal oxic conditions below (Didyk et al., 1978) and/or greater in situ microbial activity by methanogenic bacteria, an environmental change in itself (Risatti et al., 1984).

Molecular markers are sparse in these samples, but triterpenoids and polynuclear aromatic hydrocarbons (PAH) were detectable in all samples. The $\mathrm{m} / \mathrm{z}$ (mass to charge) 191 fragmentograms are shown in Figure 2, and two examples are shown as distribution plots in Figure 1E, F. The major triterpane series in all samples consists of $17 \beta(\mathrm{H}), 21 \beta(\mathrm{H})$-hopanes (Structure I) ranging from $\mathrm{C}_{27}$ to $\mathrm{C}_{32}$ (no $\mathrm{C}_{28}$ ), derived primarily from bacteria (Ourisson et al., 1979; Rohmer et al., 1980; Howard et al., 1984). A minor amount of maturation of these biomarkers has occurred to the $17 \alpha(\mathrm{H}), 21 \beta(\mathrm{H})$-hopane series (Structure II), where the C-22 S-to-R stereomer ratio for the $\mathrm{C}_{31}$ homolog ranges from 0.2 to 0.8 . This demonstrates the immaturity of the organic matter, which is further supported by the presence of various $\mathrm{C}_{29}$ and $\mathrm{C}_{30}$ triterpenes (Fig. 2). The triterpenoid distribution patterns of the samples farthest apart (Fig. 2A vs. D) are essentially identical except for the presence of one isomer of onocerane in Sample 605-66-1, 132-137 cm (Structure III, M.W. 414, Fig. 2D). The relatively simpler triterpenoid patterns in the lipids nearer the $\mathrm{K} / \mathrm{T}$ boundary (Fig. 2B, C) may indicate that a reduction of faunal

Table 1. Sample descriptions, carbon contents, and lipid yields across the K/T boundary in Hole 605 and at Stevns Klint, Denmark.

\begin{tabular}{|c|c|c|c|c|c|c|c|c|c|}
\hline Sample & Age & Lithology & $\begin{array}{c}\text { Total } \\
\text { organic } \\
\text { carbon } \\
(\%)\end{array}$ & $\begin{array}{c}\mathrm{CaCO}_{3} \\
(\%)\end{array}$ & $\begin{array}{l}\text { Total } \\
\text { hydrocarbon } \\
\text { yield } \\
(\mu \mathrm{g} / \mathrm{g})\end{array}$ & $\begin{array}{l}\text { Total } \\
n \text {-alkanes } \\
\text { (\% of total } \\
\text { extract) }\end{array}$ & $\mathrm{CPI}^{\mathrm{a}}$ & $\mathrm{C}_{\max }$ & $\mathrm{Pr} / \mathrm{Ph}$ \\
\hline $66-1,20-23 \mathrm{~cm}$ & early Paleocene & $\begin{array}{l}\text { Calcareous mudstone, } \\
\text { silt-rich, clayey }\end{array}$ & 0.19 & 13.2 & 0.52 & 0.1 & $\begin{array}{l}0.88 / 1.95 \\
(1.1)\end{array}$ & \multirow[t]{2}{*}{18} & 0.7 \\
\hline $66-1,33-36 \mathrm{~cm}$ & early Paleocene & $\begin{array}{c}\text { Calcareous mudstone, } \\
\text { silt-rich, clayey }\end{array}$ & 0.21 & 14.2 & 1.22 & 0.4 & $\begin{array}{c}1.02 / 2.5 \\
(1.12)\end{array}$ & & 0.6 \\
\hline $66-1,87-90 \mathrm{~cm}$ & late Maestrichtian & Clayey limestone & 0.34 & 30.8 & 0.52 & 0.2 & $\begin{array}{c}1.03 / 2.8 \\
(1.43)\end{array}$ & 18,27 & 1.3 \\
\hline $66-1,132-137 \mathrm{~cm}$ & late Maestrichtian & Clayey limestone & 0.11 & 56.6 & 0.33 & 0.1 & $\begin{array}{c}1.03 / 2.2 \\
(1.2)\end{array}$ & 17 & 1.2 \\
\hline \multicolumn{10}{|l|}{ Stevns Klint (outcrop) ${ }^{b}$} \\
\hline No. $2-12$ & Danian & $\begin{array}{l}\text { Basal Danian hardground } \\
\text { with Thalassinoides } \\
\text { (limestone-chalk) }\end{array}$ & & & n.d. ${ }^{c}$ & n.d. & & \multirow{3}{*}{17} & \multirow{3}{*}{0.8} \\
\hline No. $2-11$ & $\mathrm{~K} / \mathrm{T}$ fish clay & Laminated marl (clay) & & & tr. & tr. & \multirow[t]{2}{*}{$\begin{array}{c}0.99 / 2.9 \\
(1.09)\end{array}$} & & \\
\hline No. $2-10$ & Maestrichtian & $\begin{array}{l}\text { Bryozoan wackestone } \\
\text { coccolith matrix } \\
\text { (chalk) }\end{array}$ & & & n.d. & n.d. & & & \\
\hline
\end{tabular}

Note: n.d. = not detectable; tr. = traces.

a Carbon preference index of $n$-alkanes, odd-to-even, summed from $C_{13}$ to $C_{22} / C_{23}-C_{33}$ and $C_{13}-C_{33}$ in parentheses.

b Samples from Dr. S. Gartner, Texas A\&M University. 

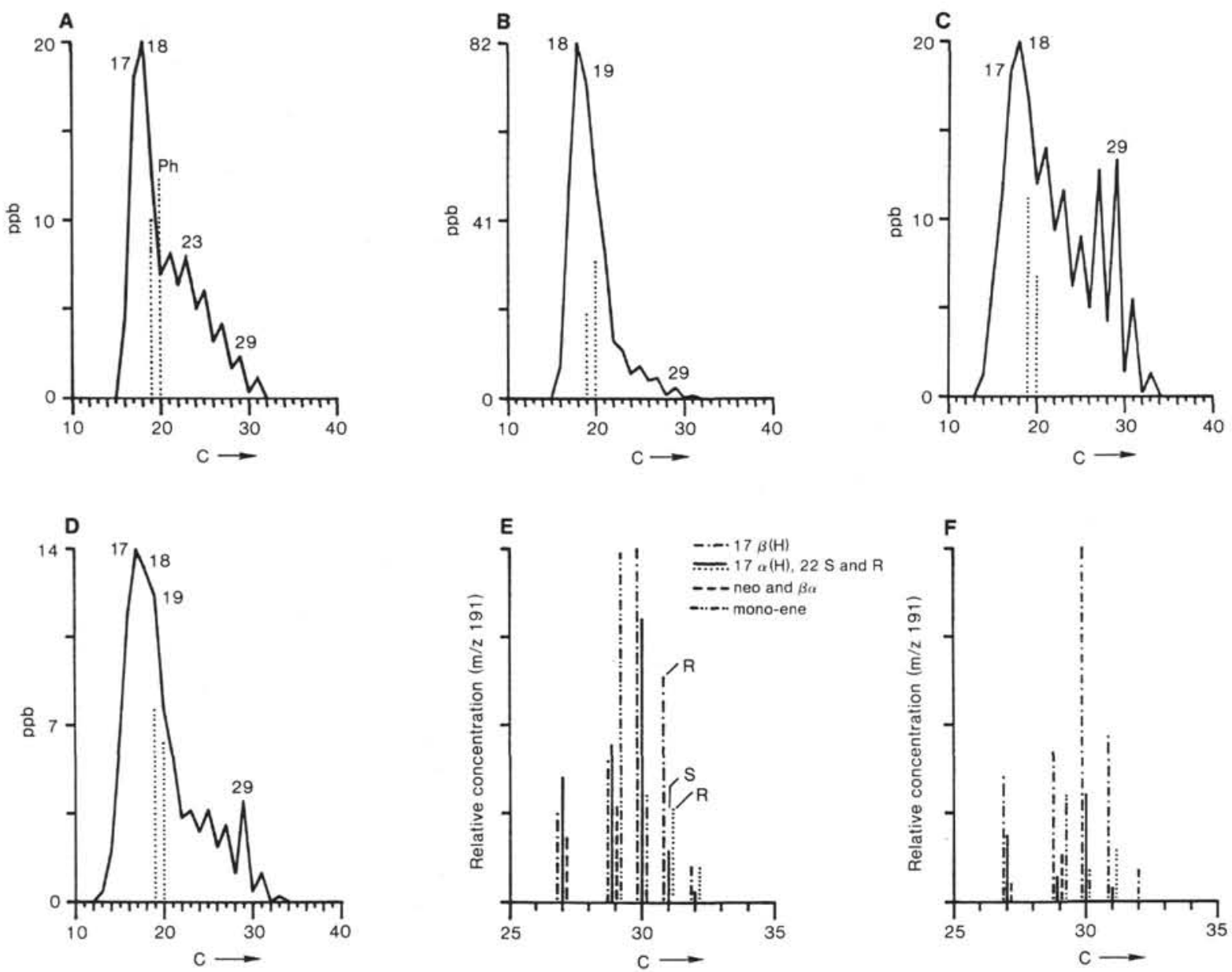

Figure 1. Distribution diagrams of $n$-alkanes (A-D $\cdots=$ isoprenoids) and triterpenoids $(\mathrm{E}, \mathrm{F})$ in the lipid extracts of the samples from Hole 605. A. Sample 66-1, 20-23 cm; B. Sample 66-1, 33-36 cm; C. Sample 66-1, 87-90 cm; D. Sample 66-1, 132-137 cm; E. Sample 66-1, 20-23 cm; F. Sample 66-1, 87-90 cm.

diversity and a possible enrichment of bacterial detritus are contributing these markers to the sediments. The presence of the onocerane is consistent with a contribution of terrestrial terpenoids to the Cretaceous section. Steranes and diasteranes, both with maxima at $\mathrm{C}_{27}$, were detectable only in Sample 605-66-1, 132-137 cm. This distribution is typical of an autochthonous algal source (Huang and Meinschein, 1979; Simoneit, 1978).

All four samples contain PAH of mainly the phenanthrene and pyrene homologous series. The phenanthrene series are shown as homologous mass fragmentograms in Figure 3 and are generally the same, with the exception of Sample 605-66-1, 87-90 cm, which has an elevated level of phenanthrene. Anthracene is not detectable. The $\mathrm{m} / \mathrm{z} 234$ fragmentograms exhibit a dominant peak of retene (Structure IV), which is an oxidation product of terrestrial plant resin detritus (Simoneit, 1977). Some examples of the homologous pyrene series (Structure V) are shown in Figure 4. Again, the distributions and relative concentrations of the major components are very similar and fluoranthene is not detectable. On consideration of the immaturity of these lipids based on the triterpenoid data, the interpretation for the presence of the major proportion of these PAH series is either oxidative transport from continental sources by rivers or atmospheric fallout of combustion products from wildfires. It should be pointed out that the greater amounts of alkyl-substituted PAH versus the unsubstituted homologs could also represent a diagenetic effect or influx of a recycled mature component. The presence of retene further supports the terrestrial origin of these PAH, and the relatively similar distributions of homologs for all samples indicates a constant and uniform source.

The compound distributions in these lipid fractions do not resemble those from the $\mathrm{K} / \mathrm{T}$ samples of DSDP Hole 577 on the Shatsky Rise (Simoneit and Beller, 1985). The latter site was in a marine paleoenvironment far removed from continental influx, whereas Hole 605 was under strong terrestrial influence at the North American continental margin.

\section{Stevns Klint}

The total extracts of lipids from three samples across the K/T boundary exposed at Stevns Klint were analyzed (Table 1). The major components in the carbonate sequences above and below the K/T boundary were $n$-fatty acids ranging from $<C_{10}$ to $C_{18}$ and CPI values of about 12 . This distribution is characteristic of a probable bacterial origin. Unsaturated acids were not detectable in these samples, indicating that these lipids are not 

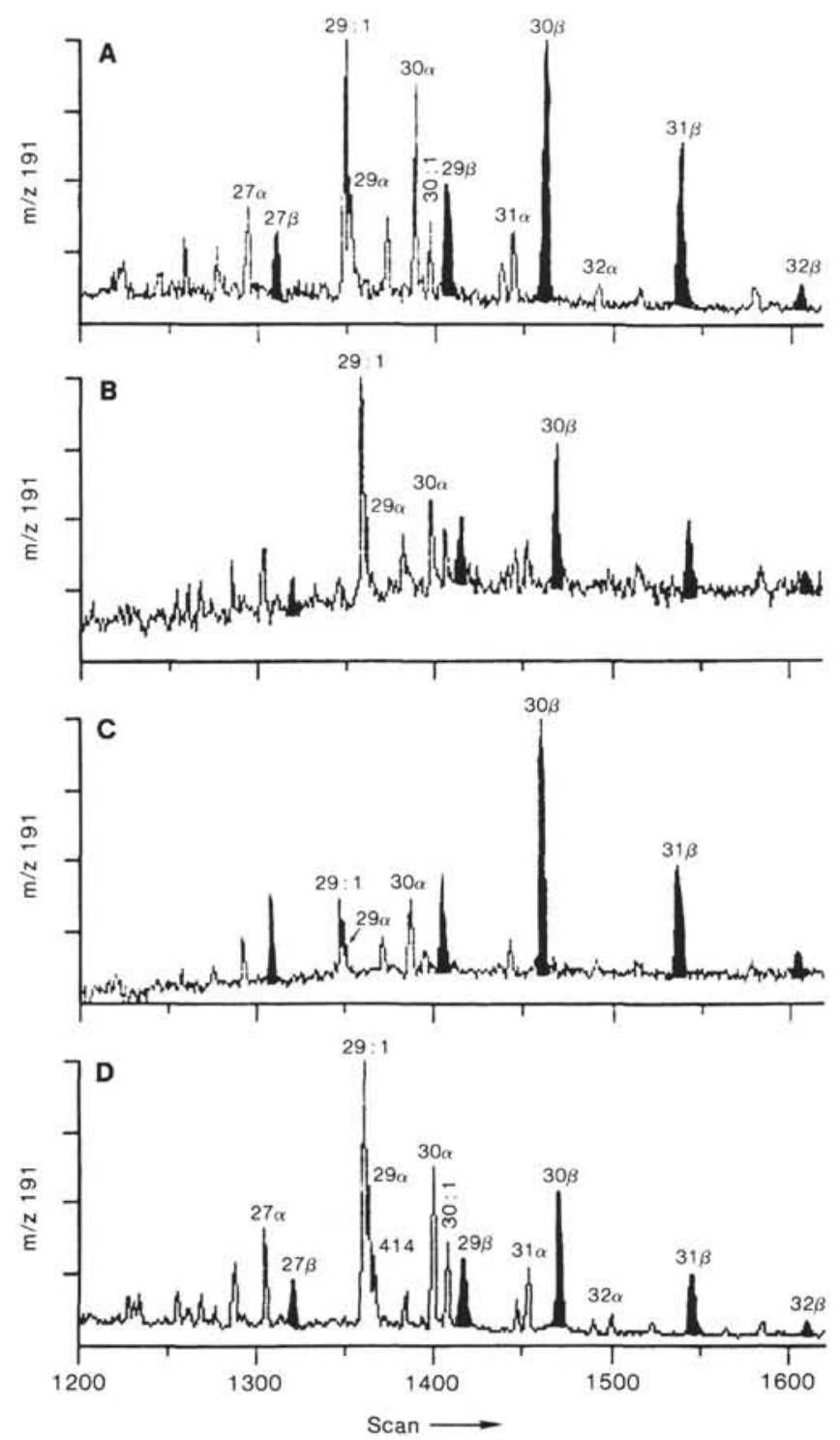

Figure 2. Mass fragmentograms $(\mathrm{m} / \mathrm{z} 191)$ for triterpenoids in the lipid extracts, Hole 605. A. Sample 66-1, 20-23 cm; B. Sample 66-1, $33-36 \mathrm{~cm}$; C. Sample $66-1,87-90 \mathrm{~cm}$; D. Sample 66-1, 132-137 cm.

of a recent origin; for example, from weathering or other contamination. The lipids of the fish clay consisted primarily of hydrocarbons; the $n$-alkanes range from $\mathrm{C}_{16}$ to $\mathrm{C}_{27}$ with a maximum at $\mathrm{C}_{17}$ and have a CPI of about 1. A major naphthenic hump is also present, ranging from $\mathrm{C}_{16}$ to $\mathrm{C}_{23}$ retention time with a maximum at $\mathrm{C}_{20}$. Both of these hydrocarbon trends indicate an origin from microbial detritus. The $\mathrm{Pr} / \mathrm{Ph}$ is about 0.8 , indicating partially euxinic paleoenvironmental conditions of sedimentation (Didyk et al., 1978) and/or greater in situ microbial activity by methanogens (Risatti et al., 1984). Minor amounts of $n$-fatty acids are also present and range from $<C_{10}$ to $C_{17}$ with a dominance of $C_{16}$ and CPI of 4.3. These again are representative of a bacterial origin.

All these samples contain resin acid markers derived from terrestrial higher plants. Dehydroabietic acid (Structure VI) occurs in all samples, but at low relative con- centration in the fish clay (Fig. 5; Simoneit, 1977). The carbonate samples above and below the $\mathrm{K} / \mathrm{T}$ boundary contain additional resin acids (Figs. 5, 6). There the major component is again dehydroabietic acid with lesser amounts of two isomers of oxodehydroabietic acid (Structure VII, Fig. 6B, D-F) and one isomer of 7-oxoabieta5,8,11,13-tetraenoic acid (Structure VIII, Fig. 6B, G). Other molecular markers (e. g., triterpenoids, steranes, $\mathrm{PAH})$ were not detectable in these samples. Whether these resin acids were syngenetic with the organic matter of the sediments or were emplaced subsequently during weathering by meteoric waters or some other means of contamination cannot be determined from these data. Such resolution would require more careful acquisition of larger samples, preferably from drill cores.

\section{CONCLUSIONS}

The transition across the $\mathrm{K} / \mathrm{T}$ boundary in Hole 605 is reflected in the lipid composition. The $n$-alkanes below the $\mathrm{K} / \mathrm{T}$ boundary contain a significant vascular plant-wax component, which is more diluted or altered above in comparison to the microbially derived $n$-alkanes present in all samples. A series of PAH and retene are present in all samples, indicating a relatively constant influx of oxidized markers from terrestrial sources or also from diagenetic processes. The hopanoid and steroid markers reflect the low maturity of the lipids and the autochthonous microbial component. Thus the biologic activity after the $\mathrm{K} / \mathrm{T}$ event left a different molecular fossil record at this site, which is under significant continental influence.

The outcrop samples from Stevns Klint contain lipid residues interpreted to derive mainly from bacteria and diterpenoidal acids derived from resinous vascular plants. The extent to which these lipids are syngenetic or derived from secondary sources needs to be resolved by better samples. Nevertheless, the carbonates above and below the K/T boundary contain essentially the same compound distributions of both terrestrial and marine origin, indicating similar degraded organic starting materials. The fish clay at the $\mathrm{K} / \mathrm{T}$ boundary is different, reflecting lower levels of primarily marine microbial lipids.

\section{ACKNOWLEDGMENTS}

We thank Dr. Stefan Gartner, Texas A\&M University, for a set of samples across the K/T boundary at Stevns Klint, Denmark; Dr. P. A. Meyers and the National Science Foundation for the well-chosen samples from Hole 605; and Drs. J. Farrington and P. A. Meyers for their reviews of this manuscript.

\section{REFERENCES}

Alvarez, L. W., Alvarez, W., Asaro, F., and Michel, H. V., 1980. Extraterrestrial cause for the Cretaceous-Tertiary extinction. Science, 208:1095-1108.

Alvarez, W., Alvarez, L. W., Asaro, F., and Michel, H. V., 1982. Current status of the impact theory for the terminal Cretaceous extinction. Geol. Soc. Am. Spec. Pap., 190:305-315.

Alvarez, W., Kauffman, E. G., Surlyk, F., Alvarez, L. W., Asaro, F., and Michel, H. V., 1984. Impact theory of mass extinctions and the invertebrate fossil record. Science, 223:1135-1141.

Christensen, L., Fregerslev, S., Simonsen, A., Thiede, J., 1973. Sedimentology and depositional environment of lower Danian fish clay from Stevns Klint, Denmark. Geol. Soc. Denm. Bull., 22:193-212. 
Didyk, B. M., Simoneit, B. R. T., Brassell, S. C., and Eglinton, G., 1978. Organic geochemical indicators of paleoenvironmental conditions of sedimentation. Nature, 272:216-222.

Hinte, J. E., van, Wise, S. W., Jr., Biart, B. N. M., Covington, J. M., Dunn, D. A., Haggerty, J. A., Johns, M. W., Meyers, P. A., Moullade, M. R., Muza, J. P., Ogg, J. G., Ikamura, M., Sarti, M., and von Rad, V., 1984. DSDP drills margin and studies paleoclimate. Geotimes, 29(4):16-18.

1985. Deep-Sea drilling on the upper continental rise off New Jersey, DSDP Sites 604 and 605. Geology, 13:397-400.

Howard, D. H., Simoneit, B. R. T., and Chapman, D. J., 1984. Triterpenoids from lipids of Rhodomicrobium vannielii. Arch. Microbiol., 137:200-204.

Huang, W. Y., and Meinschein, W. G., 1979. Sterols as ecological indicators. Geochim. Cosmochim. Acta, 43:739-745.

Kastner, M., Asaro, F., Michel, H. V., Alvarez, W., and Alvarez, L. W., 1984. The precursor of the Cretaceous-Tertiary boundary clays at Stevns Klint, Denmark, and DSDP Hole 465A. Science, 226: 137-143.

Luck, J. M., and Turekian, K. K., 1983. Osmium 187/Osmium 186 in manganese nodules and the Cretaceous-Tertiary boundary. Science, 222:613-615.

Ourisson, G., Albrecht, P., and Rohmer, M., 1979. The hopanoids, paleochemistry and biochemistry of a group of natural products. Pure Appl. Chem., 51:709-729.

Risatti, J. B., Rowland, S. J., Yon, D. A., and Maxwell, J. R., 1984. Stereochemical studies of acyclic isoprenoids-XII. Lipids of methanogenic bacteria and possible contributions to sediments. Org. Geochem., 6:93-104.

Rohmer, M., Dastillung, M., and Ourisson, G., 1980. Hopanoids from $\mathrm{C}_{30}-\mathrm{C}_{35}$ in recent muds, chemical markers for bacterial activity. Naturwissenschaft, 67:456-458.
Simoneit, B. R. T., 1977. Diterpenoid compounds and other lipids in deep-sea sediments and their geochemical significance. Geochim. Cosmochim. Acta, 41:463-476.

1978. The organic chemistry of marine sediments. In Riley, J. P., and Chester, R. (Eds.), Chemical Oceanography (Vol. 7) (2nd Ed.): New York (Academic Press): 233-311.

, 1981. Utility of molecular markers and stable isotope compositions in the evaluation of sources and diagenesis of organic matter in the geosphere. In Prashnowsky, A. A. (Ed.), The Impact of the Treibs' Porphyrin Concept on the Modern Organic Geochemistry: Würzburg (Universität Würzburg), pp. 133-158.

1982. The composition, sources and transport of organic matter to marine sediments-The organic geochemical approach. In Thompson, J. A. J., and Jamieson, W. D. (Eds.), Proc. Symp. Marine Chemistry into the Eighties: Ottawa (Nat. Res. Council of Canada), pp. 82-112.

Simoneit, B. R. T., and Beller, H. R., 1985. Lipid geochemistry of the Cretaceous/Tertiary boundary sediments, Hole 577, Deep Sea Drilling Project Leg 86. In Burckle, L. H., Heath, G. R., et al., Init. Repts. DSDP, 86: Washington (U.S. Govt. Printing Office), 671674 .

Weliky, K., Suess, E., Ungerer, C. A., Müller, P. J., and Fischer, K., 1983. Problems with accurate carbon measurements in marine sediments and particulate matter in seawater: A new approach. Limnol. Oceanogr., 28:1252-1259.

Wolbach, W. S., Lewis, R. S., and Anders, E., 1985. Cretaceous extinctions: Evidence for wildfires and search for meteoritic material. Science, 230:167-170.

Date of Initial Receipt: 31 May 1985 Date of Acceptance: 24 October 1985 


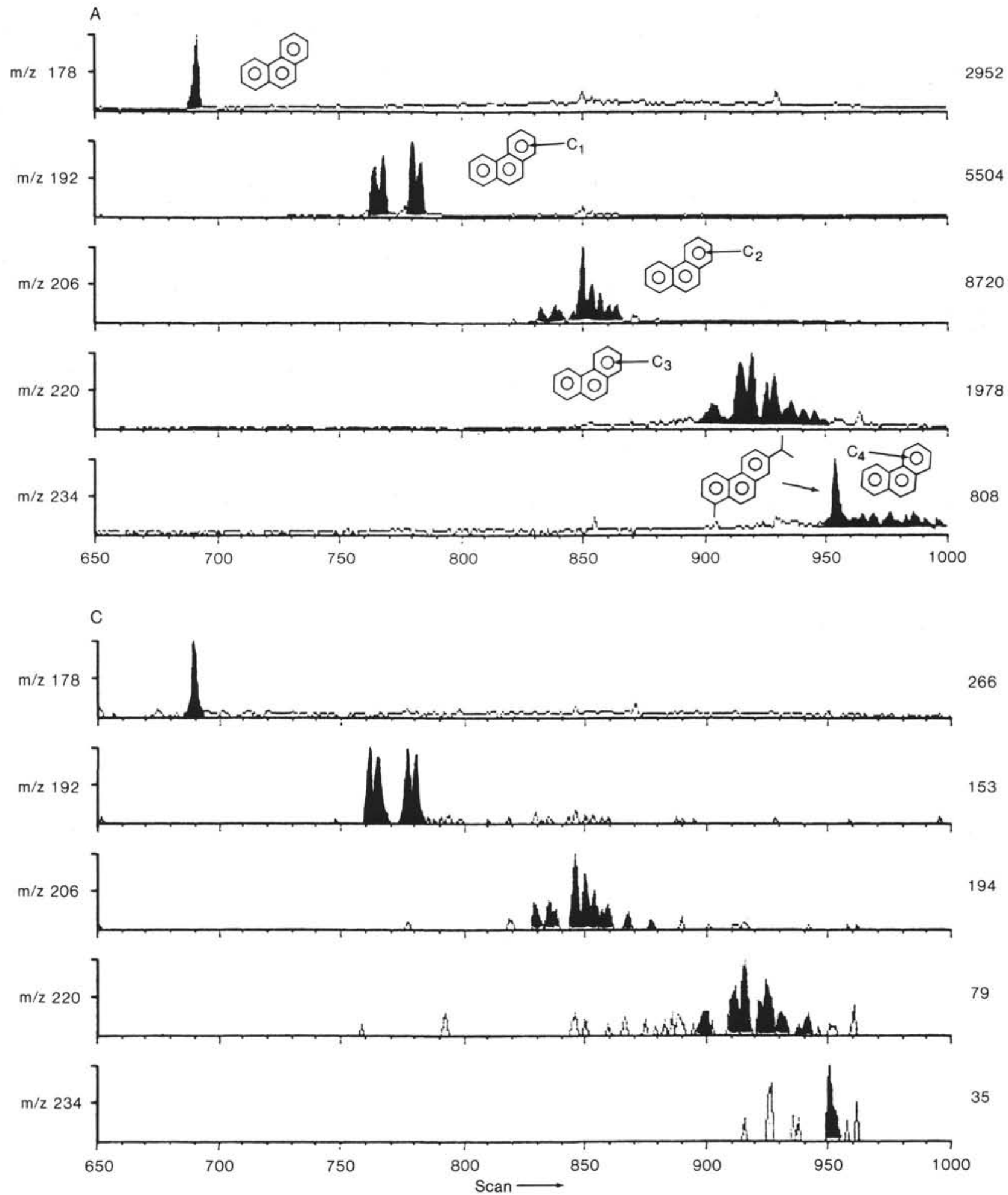

Figure 3. Mass fragmentograms for alkylphenanthrenes (m/z 178, 192, 206, 220, and 234) in the lipid extracts, Hole 605. A. Sample 66-1, 20-23 cm; B. Sample 66-1, 33-36 cm; C. Sample 66-1, 87-90 cm; D. Sample 66-1, 132-137 cm. 

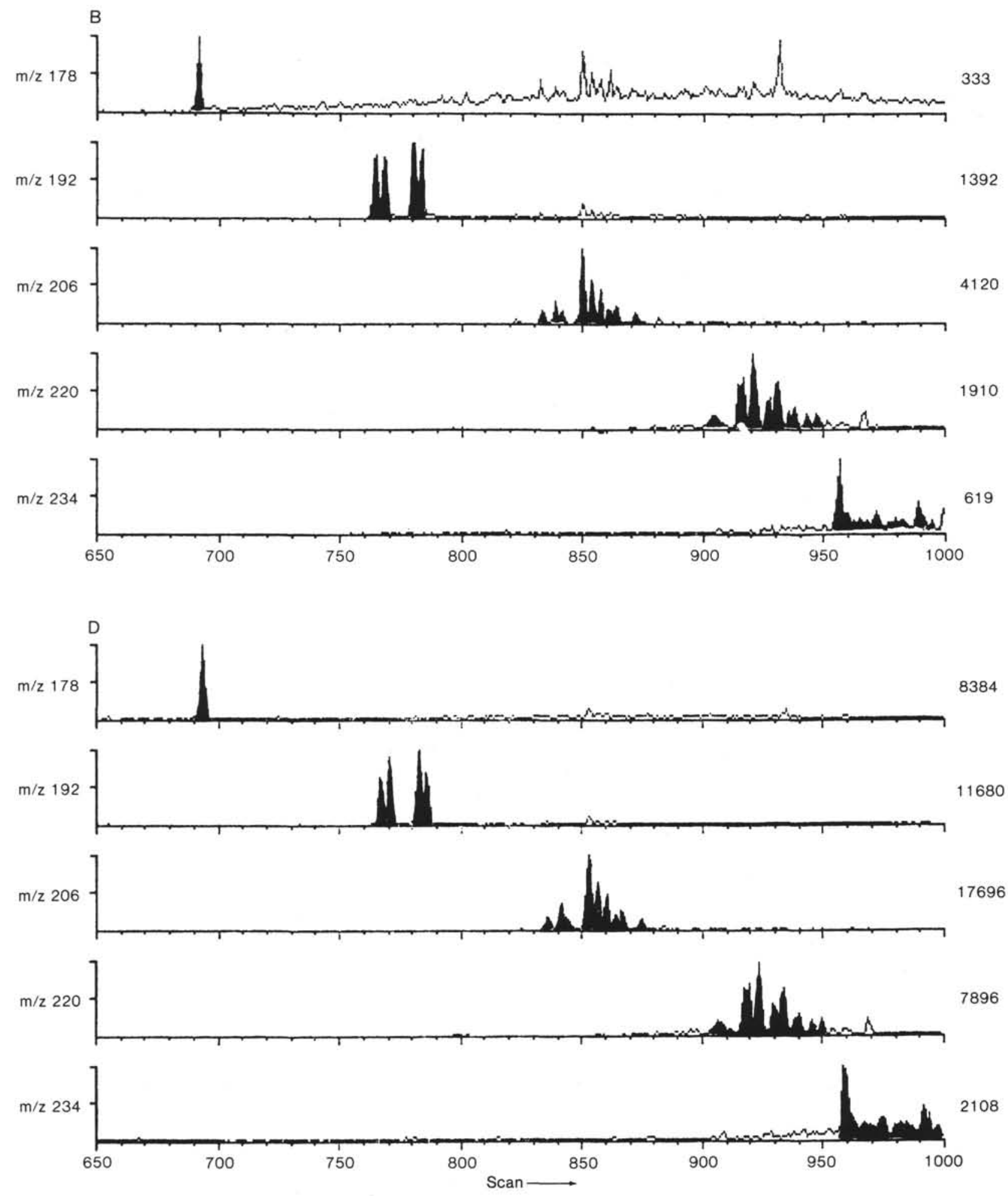

Figure 3 (continued). 


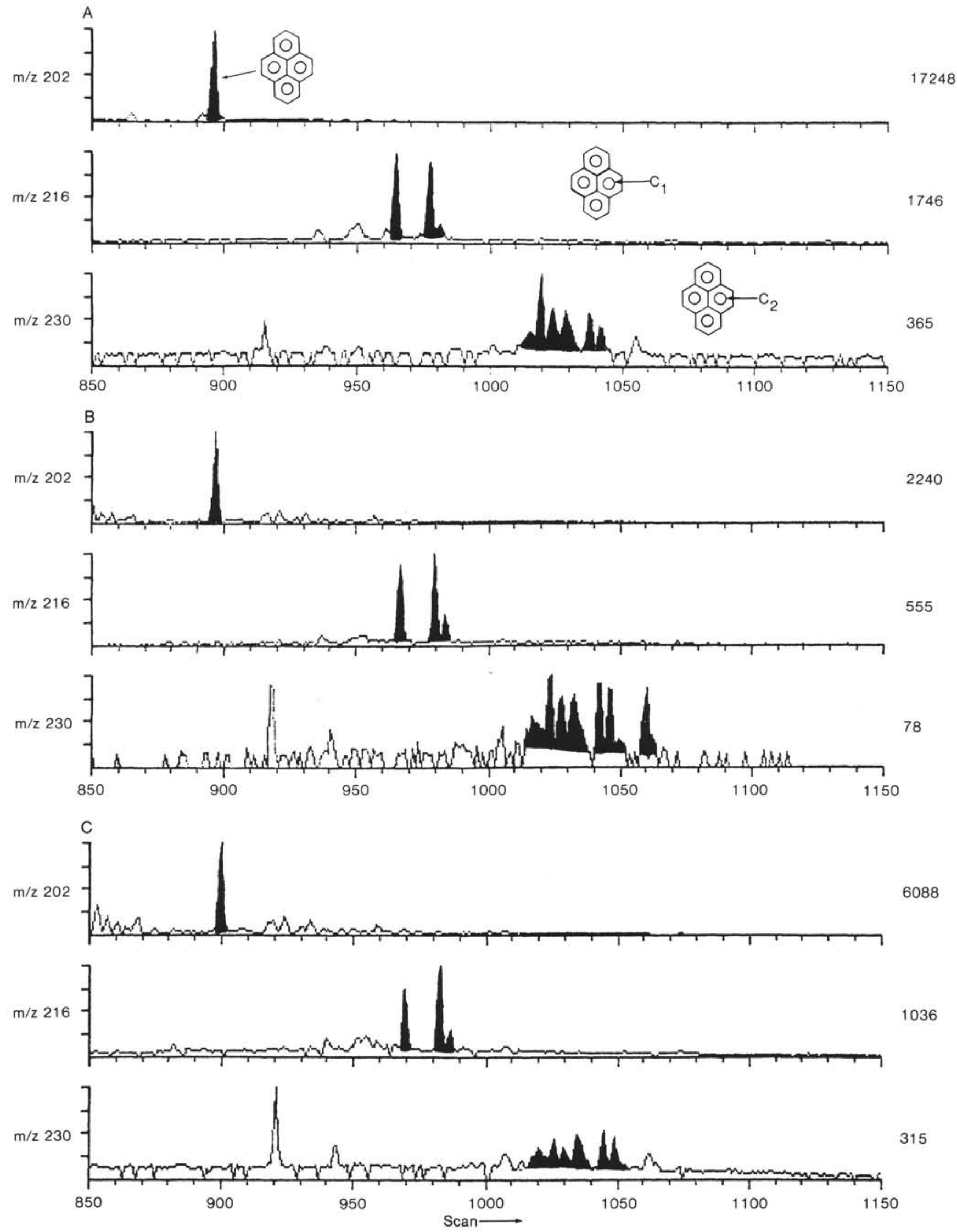

Figure 4. Mass fragmentograms for alkylpyrenes $(\mathrm{m} / \mathrm{z} 202,216$, and 230$)$ in the lipid extracts, Hole 605. A. Sample 66-1, 20-23 cm; B. Sample $66-1,33-36 \mathrm{~cm}$; C. Sample $66-1,132-137 \mathrm{~cm}$. 

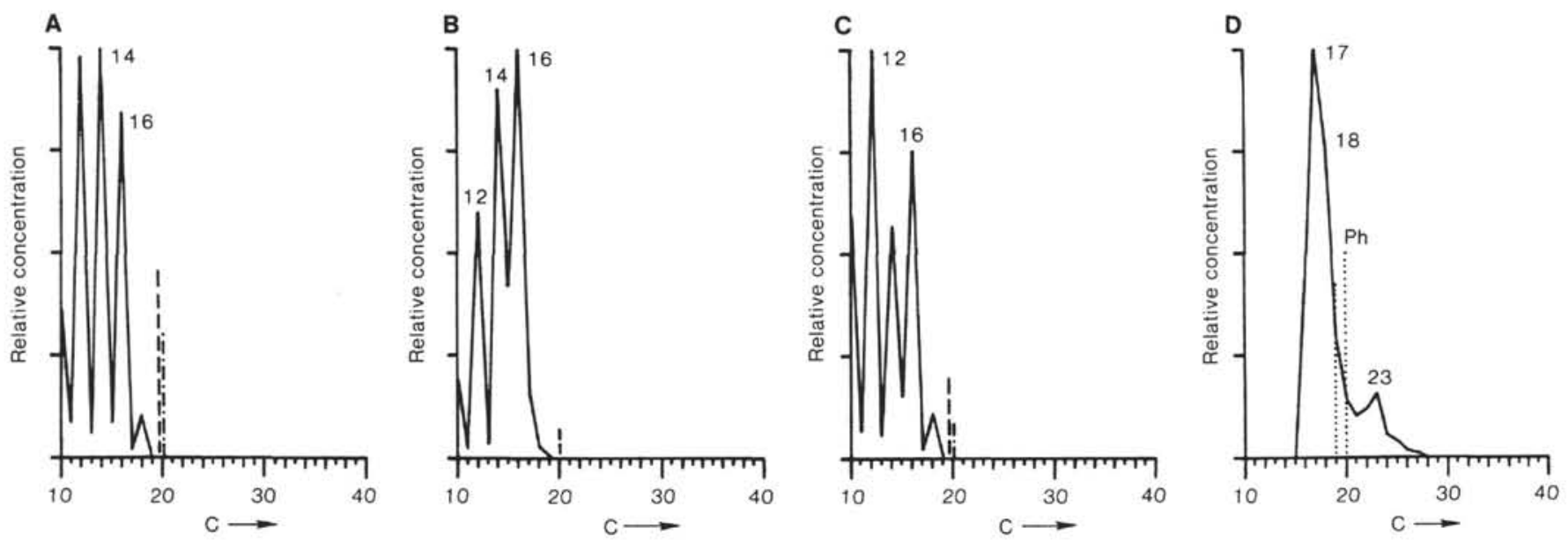

Figure 5. Distribution diagrams of $n$-fatty acids (A-C) and $n$-alkanes (D) in the total extracts of the samples from Stevns Klint (--- = dehydroabietic acid; $-\cdot \cdot \cdot=$ Structures VII and VIII; $\cdots \cdots=$ isoprenoids). A. Sample 2-12 (Danian); B, D. Sample 2-11 (fish clay); C. Sample 2-10 (Maestrichtian). 

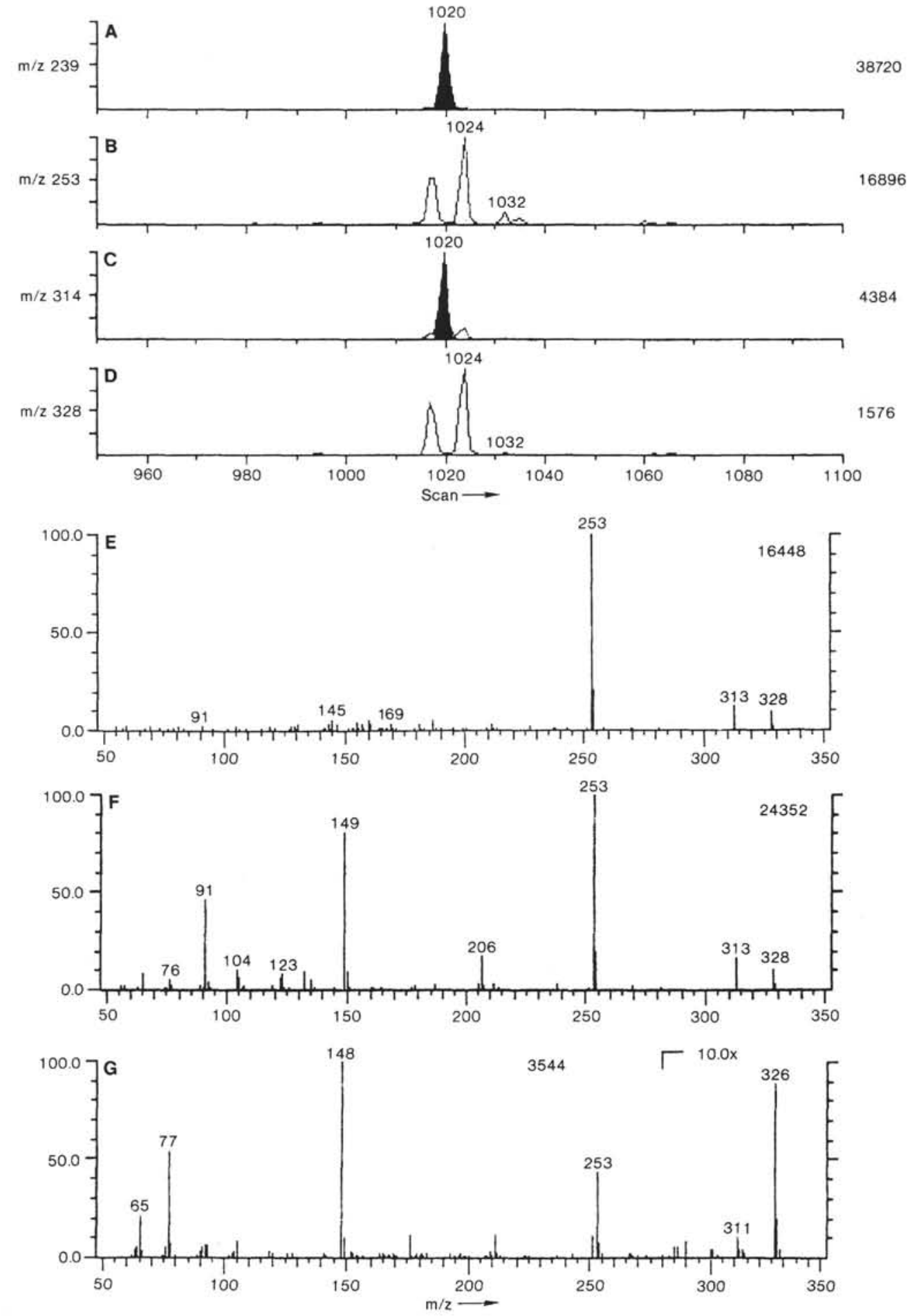

Figure 6. Mass fragmentograms and mass spectra of diterpenoid acids in Sample 2-12. A, C. m/z 239 and 314 for dehydroabietic acid; B, D. m/z 253 and 328 for oxodehydroabietic acids; E. Mass spectrum No. 1017, oxodehydroabietic acid; F. Mass spectrum No. 1024, oxodehydroabietic acid; G. Mass spectrum No. 1032, oxoabietatetraenoic acid (all mass spectra are as methyl esters). 


\section{LIPID GEOCHEMISTRY OF CRETACEOUS/TERTIARY BOUNDARY SEDIMENTS}

APPENDIX

Chemical Structures Cited

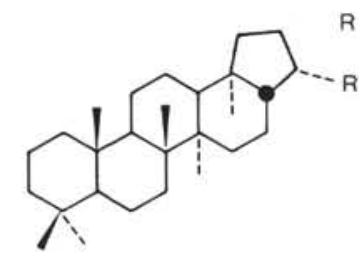

$17 \beta(\mathrm{H}), 21 \beta(\mathrm{H})$-hopanes<smiles>Cc1cccc2c1ccc1cc(C(C)C)ccc12</smiles>

1V. Retene<smiles>CC(C)c1ccc2c(c1)C(=O)CC1C(C)(C)CCC[C@]21C</smiles>

VII. 7-or 3-Oxodehydroabietic acid

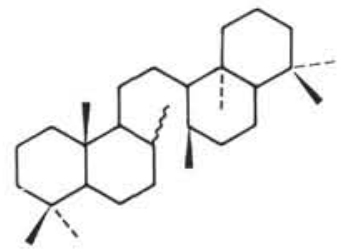

III. Onocerane

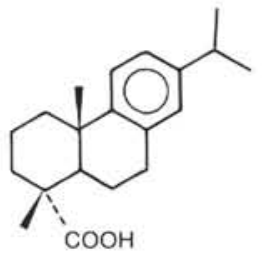

V1.

Dehydroabietic acid

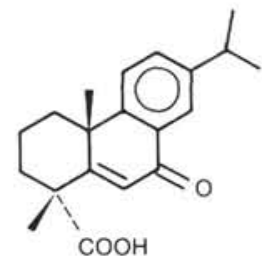

VIII 7-Oxoabieta-5, 8

11. 13-tetraen-18-oic acid 